\title{
Soil Microbial Count and Dehydrogenase Activity of Direct Seeded Rice as Influenced by Integrated Nutrient Management
}

\author{
Sangeeta $^{1} *$, B.G. Koppalkar ${ }^{1}$, Satyanaranrao ${ }^{2}$, B.K. Desai ${ }^{3}$, \\ Narayan Rao and Mahadev Swamy ${ }^{4}$ \\ ${ }^{1}$ Department of Agronomy, ${ }^{2}$ MARS, Raichur, India \\ ${ }^{3}$ Department of Agronomy, ${ }^{5}$ Department of Soil Science and Agricultural Chemistry, \\ ${ }^{4}$ Department of Agricultural Microbiology, University of Agricultural Sciences, Raichur \\ 584 104, India
}

*Corresponding author

\section{A B S T R A C T}

\begin{tabular}{|c|}
\hline Keywords \\
\hline $\begin{array}{l}\text { Direct seeded rice, } \\
\text { Varieties, Fertilizer } \\
\text { levels, Nitrogen } \\
\text { split applications, } \\
\text { Growth, Yield and } \\
\text { Economics }\end{array}$ \\
\hline Article Info \\
\hline $\begin{array}{l}\text { Accepted: } \\
\text { 12 January } 2019 \\
\text { Available Online: } \\
\text { 10 February } 2019\end{array}$ \\
\hline
\end{tabular}

\section{Introduction}

Rice (Oryza sativa L.) is a grain plant belonging to the family poaceae and genus Oryza. It is one of the most important food grains produced and consumed all over the world. Global rice demand was 439 million tonnes in 2010 and is expected to rise to 496 million tonnes in 2020 and further increase to 553 million tonnes in 2035 (Anon., 2013).

\begin{abstract}
The experiment was conducted at Agricultural College Farm, Raichur on medium black with clay loam texture during kharif season of 2016 and 2017 to know the effect of soil microbial count and dehydrogenase activity as influenced by integrated nutrient management in direct seeded rice. Pooled mean of two years indicated that among the integrated nutrient management practices significantly higher microbial count $(25.90 \mathrm{cfu}$ $\times 10^{6} \mathrm{~g}^{-1}$ of bacteria, $8.79 \mathrm{cfu} \times 10^{3} \mathrm{~g}^{-1}$ of fungi and $10.31 \mathrm{cfu} \times 10^{4} \mathrm{~g}^{-1}$ of actinomycetes at harvest and dehydrogenase activity 101.96 of $\mu \mathrm{g}$ TPF formed $\mathrm{g}^{-1}$ of soil hr${ }^{-1}$ at 45 and 109.70 of $\mu \mathrm{g}$ TPF formed $\mathrm{g}^{-1}$ of soil $\mathrm{hr}^{-1}$ at 60 DAS was recorded with the treatment, $\mathrm{T}_{2}$ ( $100 \%$ of NPK + FYM @ 10 tonnes ha $^{-1}$ ) when compared to other treatments and was found on par with the treatments $\mathrm{T}_{1}(100 \% \mathrm{NPK})$ and $\mathrm{T}_{10}(50 \%$ of recommended $\mathrm{N}$ through composted poultry manure $+50 \%$ of recommended $\mathrm{N}$ through inorganic fertilizers).
\end{abstract}

Several long-term experiments all over India indicated a decrease in rice productivity due to continuous use of chemical fertilizers. Imbalanced nutrient management under intensive cropping system and decreased soil organic matter are the key factors responsible for decline in soil quality parameters (Kang et al., 2005). Under such situation, integrated nutrient management (INM) aims to improve soil health and sustain high level of 
productivity and production (Prasad et al., 1995). Integrated nutrient management system can bring about equilibrium between degenerative and restorative activities in the soil eco-system (Upadhyay et al., 2011).

It is widely recognized that neither use of organic manures alone nor chemical fertilizers can achieve the sustainability of the yield under the modern intensive farming. Contrary to detrimental effects of inorganic fertilizers, organic manures are available indigenously which improve soil health resulting in enhanced crop yield. However, the use of organic manures alone might not meet the plant requirement due to presence of relatively low levels of nutrients. Therefore, in order to make the soil well supplied with all the plant nutrients in the readily available form and to maintain good soil health, it is necessary to use organic manures in conjunction with inorganic fertilizers to obtain optimum yields. Further, integrated nutrient management also found to influence on microbial community function and soil dehydrogenase activity.

\section{Materials and Methods}

The experiment was conducted at Agricultural College Farm, Raichur on medium black with clay loam texture during kharif season of 2016 and 2017. Experiment II was laid out on fixed site in two consecutive years in Randomized Complete Block Design (RCBD) with twelve treatments, $\mathrm{T}_{1}$ : 100 per cent of NPK, T $2: 100$ per cent of NPK + FYM @ 10 tonnes $\mathrm{ha}^{-1}, \mathrm{~T}_{3}$ : FYM equivalent to 100 per cent of recommended $\mathrm{N}, \mathrm{T}_{4}$ : vermicompost equivalent to 100 per cent of recommended $\mathrm{N}, \mathrm{T}_{5}$ : composted poultry manure equivalent to 100 per cent of recommended N, T 6 : FYM equivalent to 50 per cent of recommended $\mathrm{N}$ + vermicompost equivalent to 50 per cent of recommended $\mathrm{N}, \mathrm{T}_{7}$ : FYM equivalent to 50 per cent of recommended $\mathrm{N}+$ composted poultry manure equivalent to 50 per cent of recommended $\mathrm{N}, \mathrm{T}_{8}$ : 50 per cent of recommended $\mathrm{N}$ through $\mathrm{FYM}+50$ per cent of recommended $\mathrm{N}$ through inorganic fertilizers, $\mathrm{T}_{9}: 50$ per cent of recommended $\mathrm{N}$ through vermicompost +50 per cent of recommended $\mathrm{N}$ through inorganic fertilizers, $\mathrm{T}_{10}$ : 50 per cent of recommended $\mathrm{N}$ through composted poultry manure +50 per cent of recommended $\mathrm{N}$ through inorganic fertilizers, $\mathrm{T}_{11}$ : 25 per cent of recommended $\mathrm{N}$ through FYM + 25 per cent of recommended $\mathrm{N}$ through vermicompost +50 per cent of recommended $\mathrm{N}$ through inorganic fertilizers and $\mathrm{T}_{12}$ : 25 per cent of recommended $\mathrm{N}$ through FYM + 25 per cent of recommended $\mathrm{N}$ through poultry manure +50 per cent of recommended $\mathrm{N}$ through inorganic fertilizers with three replications. The enumeration of total bacteria, fungi and actinomycetes in free rhizosphere was carried out after the harvest of crop by serial dilution and agar plate method (Pramer and Schmidt, 1964). Dehydrogenase activity in the soil samples was determined by following the procedure as described by Casida et al., (1964). This method involves colorimetric determination of 2,3,5-triphenyl formazon (TPF) produced by the reduction of 2,3,5-triphenyl tetrazolium chloride (TTC) by soil microbes. Tetrazolium salts are representative of a unique class of compounds as terminal e- accepter and posses a high degree of water solubility. The results are expressed as $\mu \mathrm{g}$ of triphenyl formazan (TPF) formed per gram of soil per day, at 45 and 60 DAS (Days after sowing).

\section{Results and Discussion}

The significant increase in microbial population viz., bacteria, fungi and actinomycetes was observed with the addition of organic manures in combination with inorganic fertilizers. 
Table.1 Microbial activity of rice as influenced by integrated nutrient management practices

\begin{tabular}{|c|c|c|c|c|c|c|c|c|c|}
\hline \multirow[t]{2}{*}{ Treatments } & \multicolumn{3}{|c|}{$\begin{array}{l}\text { Bacteria count } \\
\left(\mathrm{cfu} \times \mathbf{1 0}^{6} \mathrm{~g}^{-1}\right)\end{array}$} & \multicolumn{3}{|c|}{$\begin{array}{l}\text { Fungi count } \\
\left(\mathrm{cfu} \times 10^{3} \mathrm{~g}^{-1}\right)\end{array}$} & \multicolumn{3}{|c|}{$\begin{array}{l}\text { Actinomycetes count } \\
\quad\left(\mathrm{cfu} \times 10^{4} \mathrm{~g}^{-1}\right)\end{array}$} \\
\hline & 2016 & 2017 & Pooled & 2016 & 2017 & Pooled & 2016 & 2017 & Pooled \\
\hline $\mathbf{T}_{1}$ & 24.77 & 25.10 & 24.94 & 8.30 & 8.63 & 8.47 & 9.76 & 10.09 & 9.92 \\
\hline $\mathbf{T}_{2}$ & 25.73 & 26.06 & 25.90 & 8.62 & 8.95 & 8.79 & 10.14 & 10.47 & 10.31 \\
\hline $\mathbf{T}_{\mathbf{3}}$ & 14.26 & 14.59 & 14.42 & 4.76 & 5.09 & 4.93 & 5.60 & 5.93 & 5.77 \\
\hline $\mathbf{T}_{4}$ & 17.26 & 17.59 & 17.43 & 5.78 & 6.11 & 5.94 & 6.80 & 7.13 & 6.97 \\
\hline $\mathbf{T}_{5}$ & 17.62 & 17.95 & 17.78 & 6.23 & 6.56 & 6.40 & 7.33 & 7.66 & 7.50 \\
\hline $\mathbf{T}_{6}$ & 15.90 & 16.23 & 16.06 & 5.33 & 5.66 & 5.49 & 6.28 & 6.61 & 6.44 \\
\hline $\mathbf{T}_{7}$ & 16.51 & 16.84 & 16.68 & 5.53 & 5.86 & 5.69 & 6.51 & 6.84 & 6.67 \\
\hline $\mathbf{T}_{8}$ & 17.03 & 17.36 & 17.19 & 5.70 & 6.03 & 5.86 & 6.73 & 7.06 & 6.90 \\
\hline $\mathbf{T}_{9}$ & 22.36 & 22.69 & 22.52 & 7.16 & 7.49 & 7.33 & 8.43 & 8.76 & 8.59 \\
\hline $\mathbf{T}_{10}$ & 24.27 & 24.60 & 24.44 & 8.13 & 8.46 & 8.30 & 9.57 & 9.90 & 9.73 \\
\hline $\mathrm{T}_{11}$ & 19.89 & 20.22 & 20.05 & 6.66 & 6.99 & 6.83 & 7.84 & 8.17 & 8.00 \\
\hline $\mathbf{T}_{12}$ & 20.82 & 21.15 & 20.99 & 6.99 & 7.32 & 7.16 & 8.22 & 8.55 & 8.38 \\
\hline S.Em \pm & 0.96 & 0.95 & 0.99 & 0.17 & 0.15 & 0.19 & 0.30 & 0.28 & 0.32 \\
\hline C. D. at $5 \%$ & 2.89 & 2.84 & 2.96 & 0.51 & 0.46 & 0.58 & 0.89 & 0.84 & 0.96 \\
\hline
\end{tabular}

$\mathbf{T}_{1}: 100 \%$ of NPK

$\mathbf{T}_{2}: 100 \%$ of NPK + FYM @ 10 tonnes ha $^{-1}$

$\mathbf{T}_{3}$ : FYM equivalent to $100 \%$ of recommended $\mathrm{N}$

$\mathbf{T}_{\mathbf{4}}$ : vermicompost equivalent to $100 \%$ of recommended $\mathrm{N}$

$\mathbf{T}_{5}$ : composted poultry manure equivalent to $100 \%$ of recommended $\mathrm{N}$

$\mathbf{T}_{6}:$ FYM equivalent to $50 \%$ of recommended $\mathrm{N}+$ vermicompost equivalent to $50 \%$ of recommended $\mathrm{N}$

$\mathbf{T}_{7}$ : FYM equivalent to $50 \%$ of recommended $\mathrm{N}+$ composted poultry manure equivalent to $50 \%$ of recommended $\mathrm{N}$
$\mathbf{T}_{8}: 50 \%$ of recommended $\mathrm{N}$ through $\mathrm{FYM}+50 \%$ of recommended $\mathrm{N}$ through inorganic fertilizers $\mathbf{T}_{\mathbf{9}}: 50 \%$ of recommended $\mathrm{N}$ through vermicompost $+50 \%$ of recommended $\mathrm{N}$ through inorganic fertilizers

$\mathbf{T}_{10}: 50 \%$ of recommended $\mathrm{N}$ through composted poultry manure $+50 \%$ of recommended $\mathrm{N}$ through inorganic fertilizers

$\mathbf{T}_{11}: 25 \%$ of recommended $\mathrm{N}$ through $\mathrm{FYM}+25 \%$ of recommended $\mathrm{N}$ through vermicompost + $50 \%$ of recommended $\mathrm{N}$ through inorganic fertilizers

$\mathbf{T}_{\mathbf{1 2}}: 25 \%$ of recommended $\mathrm{N}$ through $\mathrm{FYM}+25 \%$ of recommended $\mathrm{N}$ through poultry manure + $50 \%$ of recommended $\mathrm{N}$ through inorganic fertilizers 
Table.2 Dehydrogenase activity ( $\mu \mathrm{g}$ TPF formed $\mathrm{g}^{-1}$ of soil $\mathrm{hr}^{-1}$ ) of rice as influenced by integrated nutrient management practices

\begin{tabular}{|c|c|c|c|c|c|c|}
\hline \multirow[t]{3}{*}{ Treatments } & \multicolumn{6}{|c|}{ Dehydrogenase activity ( $\mu \mathrm{g}$ TPF formed $\mathrm{g}^{-1}$ of soil $\mathrm{hr}^{-1}$ ) } \\
\hline & \multicolumn{3}{|c|}{45 DAS } & \multicolumn{3}{|c|}{60 DAS } \\
\hline & 2016 & 2017 & Pooled & 2016 & 2017 & Pooled \\
\hline T1 & 96.00 & 100.33 & 98.16 & 106.24 & 110.57 & 108.41 \\
\hline $\mathbf{T} 2$ & 99.80 & 104.13 & 101.96 & 107.54 & 111.87 & 109.70 \\
\hline T3 & 54.23 & 58.56 & 56.39 & 58.16 & 62.49 & 60.33 \\
\hline $\mathbf{T 4}$ & 66.30 & 70.63 & 68.46 & 71.06 & 75.39 & 73.23 \\
\hline T5 & 71.60 & 75.93 & 73.77 & 76.73 & 81.06 & 78.90 \\
\hline T6 & 60.90 & 65.23 & 63.06 & 65.22 & 69.55 & 67.38 \\
\hline $\mathbf{T 7}$ & 63.33 & 67.66 & 65.49 & 67.87 & 72.20 & 70.03 \\
\hline T8 & 65.37 & 69.70 & 67.54 & 70.08 & 74.41 & 72.24 \\
\hline T9 & 82.51 & 86.84 & 84.67 & 88.41 & 92.74 & 90.57 \\
\hline T10 & 95.31 & 99.64 & 97.48 & 106.14 & 110.47 & 108.30 \\
\hline T11 & 76.70 & 81.03 & 78.86 & 82.19 & 86.52 & 84.35 \\
\hline T12 & 80.39 & 84.72 & 82.56 & 86.13 & 90.46 & 88.30 \\
\hline S. Em \pm & 2.21 & 2.20 & 2.23 & 2.40 & 2.39 & 2.42 \\
\hline C. D. at $5 \%$ & 6.64 & 6.61 & 6.69 & 7.21 & 7.18 & 7.26 \\
\hline
\end{tabular}

DAS - Days after sowing

$\mathbf{T}_{1}: 100 \%$ of NPK

$\mathbf{T}_{2}: 100 \%$ of NPK + FYM @ 10 tonnes ha ${ }^{-1}$

$\mathbf{T}_{3}$ : FYM equivalent to $100 \%$ of recommended $\mathrm{N}$

$\mathbf{T}_{4}$ : vermicompost equivalent to $100 \%$ of recommended $\mathrm{N}$

$\mathbf{T}_{5}:$ composted poultry manure equivalent to $100 \%$ of recommended $\mathrm{N}$

$\mathbf{T}_{6}$ : FYM equivalent to $50 \%$ of recommended $\mathrm{N}+$ vermicompost equivalent to $50 \%$ of recommended $\mathrm{N}$

$\mathbf{T}_{7}$ : FYM equivalent to $50 \%$ of recommended $\mathrm{N}+$ composted poultry manure equivalent to $50 \%$ of recommended $\mathrm{N}$
$\mathrm{T}_{8}: 50 \%$ of recommended $\mathrm{N}$ through FYM $+50 \%$ of recommended $\mathrm{N}$ through inorganic fertilizers $\mathbf{T}_{9}: 50 \%$ of recommended $\mathrm{N}$ through vermicompost $+50 \%$ of recommended $\mathrm{N}$ through inorganic fertilizers

$\mathbf{T}_{10}: 50 \%$ of recommended $\mathrm{N}$ through composted poultry manure $+50 \%$ of recommended $\mathrm{N}$ through inorganic fertilizers

$\mathbf{T}_{11}: 25 \%$ of recommended $\mathrm{N}$ through $\mathrm{FYM}+25 \%$ of recommended $\mathrm{N}$ through vermicompost + $50 \%$ of recommended $\mathrm{N}$ through inorganic fertilizers

$\mathbf{T}_{12}: 25 \%$ of recommended $\mathrm{N}$ through FYM $+25 \%$ of recommended $\mathrm{N}$ through poultry manure + $50 \%$ of recommended $\mathrm{N}$ through inorganic fertilizers 
The inorganic fertilizers i.e., $\mathrm{T}_{2}(100 \% \mathrm{NPK}+$ FYM @ 10 tonnes ha $\left.{ }^{-1}\right)\left(25.90 \mathrm{cfu} \times 10^{6} \mathrm{~g}^{-1}\right.$, $8.79 \mathrm{cfu} \times 10^{3} \mathrm{~g}^{-1}$ and $\left.10.31 \mathrm{cfu} \times 10^{4} \mathrm{~g}^{-1}\right)$ and was on par with $\mathrm{T}_{1}(100 \%$ of NPK) $(24.94 \mathrm{cfu}$ $\times 10^{6} \mathrm{~g}^{-1}, 8.47 \mathrm{cfu} \times 10^{3} \mathrm{~g}^{-1}$ and $9.92 \mathrm{cfu} \times 10^{4}$ $\left.\mathrm{g}^{-1}\right)$ and $\mathrm{T}_{10}(50 \%$ of recommended $\mathrm{N}$ through composted poultry manure $+50 \%$ of recommended $\mathrm{N}$ through inorganic fertilizers) $\left(24.44 \mathrm{cfu} \times 10^{6} \mathrm{~g}^{-1}, 8.30 \mathrm{cfu} \times 10^{3} \mathrm{~g}^{-1}\right.$ and $9.73 \mathrm{cfu} \times 10^{4} \mathrm{~g}^{-1}$ ) and lower microbial population was observed with FYM equivalent to 100 per cent of recommended $\mathrm{N}$ $\left(\mathrm{T}_{3}\right)\left(14.42 \mathrm{cfu} \times 10^{6} \mathrm{~g}^{-1}, 4.93 \mathrm{cfu} \times 10^{3} \mathrm{~g}^{-1}\right.$ and $5.77 \mathrm{cfu} \times 10^{4} \mathrm{~g}^{-1}$ ), respectively (Table 1 ). Significant improvement in the population of soil micro-organisms viz., bacteria, fungi, actinomycetes, and dehydrogenase activity were recorded with integrated nutrient management practices This was due to the presence of easily metabolizable compounds at the beginning of the crop growth and also under active growth phase releasing higher amounts of root exudates, supporting numerous and diverse micro flora.

The dehydrogenase activity also followed similar trend as that of microbial load in soil. Among the integrated nutrient management practices, significantly higher dehydrogenase activity was recorded with $\mathrm{T}_{2}$ i.e., the application of 100 per cent of NPK + FYM @ 10 tonnes $\mathrm{ha}^{-1}$ (101.96 and $109.70 \mu \mathrm{g}$ TPF formed $\mathrm{g}^{-1}$ of soil $\left.\mathrm{hr}^{-1}\right)$ and was on par with $\mathrm{T}_{1}$ i.e., 100 per cent of NPK (98.16 and 108.41 $\mu \mathrm{g}$ TPF formed $\mathrm{g}^{-1}$ of soil $\mathrm{hr}^{-1}$ ) and $\mathrm{T}_{10}$ i.e., 50 per cent of recommended $\mathrm{N}$ through composted poultry manure +50 per cent of recommended $\mathrm{N}$ through inorganic fertilizers (97.48 and $108.30 \mu \mathrm{g}$ TPF formed $\mathrm{g}^{-1}$ of soil $\mathrm{hr}^{-1}$ ) whereas significantly lower dehydrogenase activity was observed with the application of FYM equivalent to 100 per cent of recommended $\mathrm{N}\left(\mathrm{T}_{3}\right)$ (56.39 and $60.33 \mu \mathrm{g}$ TPF formed $\mathrm{g}^{-1}$ of soil $\mathrm{hr}^{-1}$ ) (Table 2), respectively at 45 and $60 \mathrm{DAS}$. The higher dehydrogenase activity may be due to application of combination of inorganic fertilizers with organic manures as well as maximum moisture availability and higher microbial activities. These results are in accordance with Nagendra (2015) who reported that the application of $100 \%$ recommended dose of NPK through chemical fertilizers recorded lower enzyme activities than the INM treatments which is attributed to lack of sufficient substrate i.e. organic carbon which acts as an energy source and food for proliferating the microbial population. Similar results are also reported by Sriramachandrakharn et al., (1997).

The lower activity of dehydrogenase at later stage compared to earlier stage could be due to decrease in moisture availability. The dehydrogenase activity showed an increasing trend with the age of the crop. It increased from mid tillering stage to panicle initiation stage, exhibited highest activity at panicle initiation stage and there after the activity decreased at maturity. The activities of dehydrogenase enzyme in the soil system is very important as it gives indications of the potential of the soil to support biochemical processes which are essential for maintaining soil fertility (Joychim et al., 2008). Significantly higher dehydrogenase activity in integrated nutrient management practices was due to addition of organic matter which in turn increased microbial activity and microbial biomass and consequently increased activity of dehydrogenase (Tejada and Gonzalez, 2009). The applied organic sources were able to get mineralized rapidly in early days of incubation hence, there was more mineralization than immobilization which consequently provided sufficient nutrition for the proliferation of microbes and their activities in terms of soil dehydrogenase. Similar observations were noted by Joychim et al., (2008), Lakshmi et al., (2014) and Nagendra (2015). 


\section{References}

Anonymous, 2013, Area, production and productivity of rice in India. www.indiastat.com.

Joychim, H. J., Makoi, R., Patrick, A. and Dakidemin, N., 2008, Selected soil enzymes: examples of their potential roles in the ecosystem. African $J$. Biochem., 7: 181-191.

Kang, G. S., Beri, V., Sidhu, B. S. and Rupela O. P., 2005, A new index to assess soil quality and sustainability of wheatbased cropping systems. Bio. Fert. Soils, 41: 389-398.

Lakshmi, S. R., Rao, P. C., Sreelatha, T., Padmaja, G., Madhavi, M., Rao, P. V. and Sireesha, A., 2014, Biochemical changes in submerged rice soil amended with different vermicomposts under integrated nutrient management. $J$. Indian Soc. Soil Sci., 62(2): 131-139.

Nagendra, V., 2015, Influence of rice production systems and nutreint management practices on rice yield and soil properties. M.Sc. Thesis, Prof.
Jayashankar Telangana state Agric. Univ.

Prasad, B., Prasad, J. and Prasad, R., 1995, Nutrient management for sustained rice and wheat production in calcareous soil amended with green manures, organic manure and zinc (ENG). Fert. News, 40(3): 39-41.

Sriramachandrakharn, M. V., Ramanathan, G. and Ravichandran, M., 1997, Effect of different organic manures on enzyme activities in a flooded rice soil. Oryza, 34(1): 39-42.

Tejada, M. and Gonzalez, J. L., 2009, Application of vermicomposts to rice crop: effects on soil biological properties and rice quality and yield. Agron. J., 101: 336-344.

Upadhyay, V. B., Jain, V., Vishwakarma, S. K. and Kumhar, A. K., 2011, Production potential, soil health, water productivity and economics of rice based cropping systems under different nutrient sources. Indian J. Agron., 56(4): 311-316.

\section{How to cite this article:}

Sangeeta, B.G. Koppalkar, Satyanaranrao, B.K. Desai, Narayan Rao and Mahadev Swamy. 2019. Soil Microbial Count and Dehydrogenase Activity of Direct Seeded Rice as Influenced by Integrated Nutrient Management. Int.J.Curr.Microbiol.App.Sci. 8(02): 1345-1350. doi: https://doi.org/10.20546/ijcmas.2019.802.157 